\title{
EVALUATING THE APPLICATION OF RESTORATIVE JUSTICE AT THE MANGAUNG ONE-STOP CHILD JUSTICE CENTRE
}

\section{Roelf Reyneke \& Mariëtte Reyneke ${ }^{1}$}

\section{INTRODUCTION}

The South African criminal justice system is largely punitive, retributive and adversarial in nature; this was also true for the child justice systems, until the acknowledgement and advancement of children's rights. The United Nations Convention on the Rights of the Child (CRC) deals specifically with children in conflict with the law. Article 40 of the CRC provides inter alia that the child in conflict with the law has a right to the promotion of his or her sense of dignity and worth, and the reinforcement of the child's respect for human rights and fundamental freedoms of others. State parties also have an obligation to develop a comprehensive juvenile justice system through laws, procedures, authorities and institutions. Thus states are required to have specialised units within the police, judiciary, court system, prosecution and legal representation in order to deal with children in conflict with the law. Furthermore, state parties are required to have alternatives in place to deal with children in conflict with the law so as to ensure the limitation of resorting to judicial proceedings. The importance of diverting the child away from the criminal justice system is thus emphasised (Hodgkin \& Newell, 2007:601-602, 616, 618). In line with international standards, the South African Constitution also guarantees, in section $28(1)(\mathrm{g})$, that children should be detained only as a measure of last resort and then kept separate from adults.

South Africa ratified the United Nations CRC in June 1995. This ratification means that South Africa is bound to the international standards for child justice and therefore has had to bring South African law in line with these international standards. In 1996 a Project Committee of the then South African Law Reform Commission (SALRC) consequently undertook an investigation into child justice in South Africa to inform legislation and practice that would uphold the CRC as well as the Constitution of South Africa (Gallineti, Kassan \& Ehlers, 2006:8). After a very protracted process the new legislation was finally adopted on 7 May 2008 and the new Child Justice Act 75 of 2008 (from here on "the Act") comes into operation on 1 April 2010.

Section 89 of the Act (75 of 2008) makes provision for the establishment and maintenance of One-Stop Child Justice Centres. The Mangaung One-Stop Child Justice Centre (from here on "the Centre") was opened in May 2002 as a pilot project in Bloemfontein. There are currently a number of other One-Stop Child Justice Centres in South Africa. The centres aim to have all the role players in the child justice system under one roof in order to deliver a professional service to children. It is envisaged that more of these centres will be established once the new Act comes into operation.

There are police officers, probation officers, assistant probation officers, a legal adviser, a representative of the National Institute for Crime Prevention and Rehabilitation of Offenders (NICRO), and court personnel at the Mangaung One-Stop Child Justice Centre. There is office space for all the personnel, a reception area, a police station, holding facilities, consultation rooms, a conference room and a dedicated court room, all under one roof.

\footnotetext{
${ }^{1}$ This material is based upon work financially supported by the National Research Council.
} 
This multidisciplinary team's main focus and current practice model are in line with the objectives of the Child Justice Act. They protect the rights of children by promoting the spirit of ubuntu through fostering children's sense of dignity and worth, and by reinforcing children's respect for human rights and fundamental freedoms. Their work supports reconciliation by means of a restorative justice response, and they involve parents, families, victims and other members of the community where appropriate to reintegrate the children into their communities. The Centre aims to break the cycle of crime, to encourage children to become law-abiding and productive adults, and to prevent children from exposure to the adverse effects of the formal criminal justice system. Lastly, they promote cooperation between different role players to ensure an integrated and a holistic approach to child justice.

As a result of the success of implementing these objectives, the Centre won a United Nations award for best practices in 2008 and is currently applying the provisions of the new Child Justice Act as far as possible within the existing legislation. Once the new legislation comes into effect, there will be a few minor changes in their operations. As this Centre is seen as a model for service delivery to children in conflict with the law, it was deemed necessary to evaluate the restorative work done by the probation staff.

In this article the research aims and methods will be discussed and attention will be given to the concept of restorative justice. The main tasks of the probation staff in promoting restorative justice and diversion services rendered to children in conflict with the law will be discussed, followed by an evaluation of the general restorativeness of diversion programmes. Lastly, some of the most pressing challenges experienced at the Centre are identified and some recommendations are made.

\section{AIMS AND METHODS}

One of the five primary aims of the Act is to expand and entrench the principles of restorative justice in the criminal justice system for children who are in conflict with the law, while also ensuring that they take responsibility for their actions and holding them accountable for crimes committed (Child Justice Act, 75 of 2008). This article explores the work of the probation staff at the Mangaung One-Stop Child Justice Centre. The foundations of restorative justice are illustrated and its implementation is described and evaluated. Lastly, appropriate recommendations for the improvement of services, from a restorative justice perspective, are made throughout the discussion.

A qualitative research method was employed in this study. To solicit a deeper understanding of the work of this Centre, primary data are presented in the form of a case study. This case study reflects primarily on the tasks of the probation staff in the context of the practice model utilised by the Centre from a restorative justice perspective. Special attention is given to the assessment of the youth offender and the therapeutic services, especially diversion that flows from the process.

According to Fouché (2007:272), the exploration and description of a case study takes place through detailed, in-depth data collection methods, involving multiple sources of information that are rich in context. These may include interviews, documents, observations and archival records. Adding to this, Patton (2002:306) is of the opinion that by using a combination of procedures such as those mentioned, the researcher can better validate and cross-check findings. Each data source has it strengths and weaknesses, and through triangulation the strengths of one procedure can compensate for the weaknesses of another approach. During this particular research several reports on the Centre were studied and the Centre was visited for a 
number of days. During these visits the activities at the Centre were observed and evaluated, and representatives of all the role players were interviewed, some of them more than once, to determine what practices are employed at the Centre. Documents drafted by the Centre and reports by other independent evaluators on the Centre were also analysed and cross-referenced in interviews.

\section{RESTORATIVE JUSTICE}

The philosophy of restorative justice will be discussed briefly to explain the essence of this approach to justice and to provide the background against which the roles and tasks of the probation staff and diversion programmes at the Centre could be scrutinised. The aim of these introductory paragraphs is to orientate the reader towards the basic concepts. Later on in the discussion more restorative justice theory will be incorporated into the explanation of the work at the Centre in order to show how the programmes conform to the principles of restorative justice.

\section{The restorative justice philosophy}

According to Zehr (2002:5), the term restorative justice encompasses "a variety of programs and practices, at its core is a set of principles, a philosophy, an alternate set of guiding questions. Ultimately, restorative justice provides an alternative framework for thinking about wrongdoing".

The concept and philosophy of restorative justice emerged during the 1970s and the 1980s in the United States and Canada. In the evolution of restorative justice, practice preceded theory in that mediation, circles and conferencing were used to respond to criminal cases before there was an understanding that these practices entailed restorative justice (McCold, 2006:23-24; Zehr, 2002:42).

Zehr (2002:19) states that restorative justice is based upon an old, common sense understanding of wrongdoing. It is seen that crime is a violation of people and of interpersonal relationships; violations create obligations, and the central obligation is to put right the wrongs. He is further of the opinion that underlying this understanding of wrongdoing is an assumption about society: we are interconnected.

South Africa, with its unique composition of different cultures and traditions, has its own unique but also universal values. Broodryk (2002:3) supports this notion when he refers to there being one noticeable cultural tradition that is not only noticeable in South Africa, but across Africa; this is of course Ubuntu-Botho, which means "A person is a person because of or through others". This is the indigenous world view of humaneness and can be described as the capacity in African culture to express compassion, reciprocity, dignity, humanity and mutuality in the interest of building and maintaining communities with justice and mutual caring (Poovan, Du Toit \& Engelbrecht, 2006:17). The promotion of the spirit of ubuntu in the child justice system is one of the objectives of the Child Justice Act.

Children are treated in line with this objective at the Centre. Humaneness is initiated from the minute the child enters the Centre. During the whole process the child is attended to in a warm and tolerant manner. Staff will, for example, not shout at the child and the court proceedings are informal in order to strengthen the value of compassion. Children are respected in that they take part in the entire process and may contribute to the planning of what is going to happen to them. The children's dignity is respected in several ways, including through the physical surroundings. For instance, the cells are child-friendly with floor heating and the building is 
painted in friendly colours. In order to show physical humaneness, the children receive a toothbrush, facecloth and soap with which to clean themselves. There is a washing machine that is used to wash the children's clothes, if necessary, to ensure the children appear decently in court. These values are also strengthened during the diversion programmes that the children attend. It could be said that in South Africa ubuntu lends restorative justice and restorative programmes their own indigenous character.

Part of the essence of restorative justice is that it seeks to provide an alternative approach to the management of crime and justice; it provides a restorative philosophy. This philosophy is comprised of five basic principles (Zehr, 2002:32-33):

- There should be a focus on the harms and the consequent needs of the victims, the communities and the offenders;

- The obligations of the offenders, community and society that result from those harms should be addressed;

- Inclusive collaborative processes should be used;

- Those with a legitimate stake in the situation, including victims, offenders, community members and society should be involved;

- Seek to put right the wrongs.

\section{FIGURE 1 \\ THE RESTORATIVE JUSTICE CIRCLE}

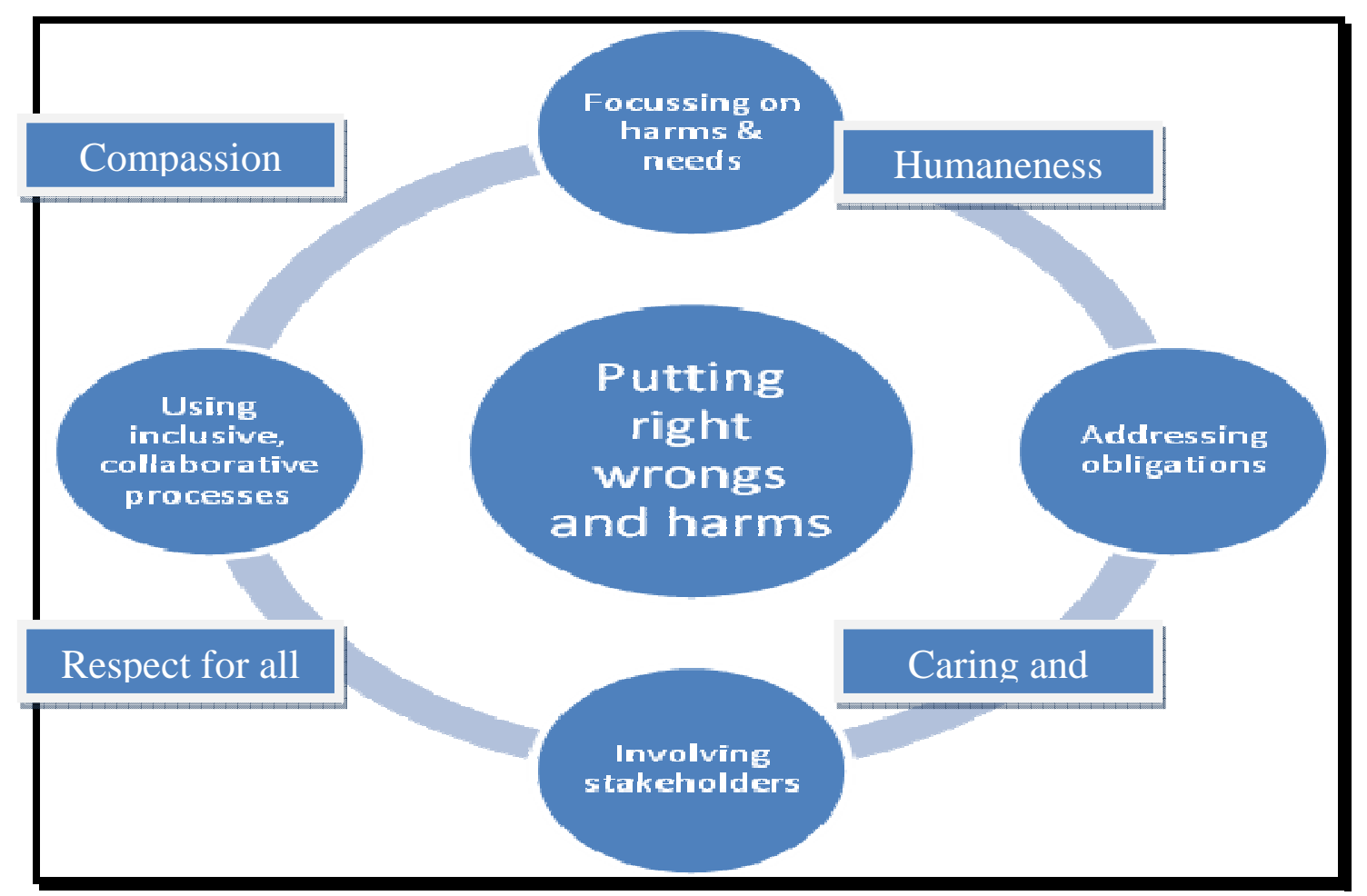

(Zehr, 2002:33; Broodryk, 2002:19, adapted)

The core values of ubuntu and the principles of restorative justice are set out in Figure 1. Programmes that claim to be restorative in nature should reflect these basic guidelines. At the centre of the restorative justice approach is putting right the wrongs and harms caused by the crime or the wrongdoing. In putting things right it is important to address the obligations of the 
different parties involved by connecting all the stakeholders, through using inclusive, collaborative processes and through a focus on the harms and needs of the people involved.

\section{Restorative justice in child justice}

South Africa's restorative response to child justice is captured in the Child Justice Act (75 of 2008). When society uses a tit-for-tat response to the punishment of youths - and youths in conflict with the law in particular - one fritters away the power to generate restorative changes in them. Punishment shows a short-sighted focus on changing external behaviour while virtually ignoring or sometimes even exacerbating the internal causes of infractions (Brendtro \& Larson, 2006:27). A need for a restorative approach to the sentencing and/or management of young offenders is thus needed.

Restorative justice has been defined both as a process and a set of values (Morrison, 2007:75). Therefore the Child Justice Act describes restorative justice as "an approach to justice that aims to involve the child offender, the victim, the families concerned and community members to collectively identify and address harms, needs and obligations through accepting responsibility, making restitution, taking measures to prevent a recurrence of the incident and promoting reconciliation" (Child Justice Act, 2008).

Morrison (2007:73) sees restorative justice as "addressing basic social and emotional needs of individuals and communities; particularly in the context of responding to harmful behaviour to oneself and others". From these definitions it is clear that this approach not only focuses on the social and emotional needs of the child offender, but also on the victim, families concerned and the community in a collective manner. It is also evident that restorative justice aims to address harms, prevent the further recurrence of the incident and, in the long term, focuses on the promotion of reconciliation. What is particularly important is the focus on the social and emotional needs of these groups.

\section{Restorative process and restorative programmes}

Skelton and Batley (2006:7) mention that "In the early days of the development of restorative justice, it was common for a wide range of processes and programmes to be described as restorative". This then meant that all diversion programmes were seen as restorative as their focus was on finding alternatives for the sentencing of youths in conflict with the law.

A restorative processes refer to any process in which the victim, the offender and, where appropriate, any other individuals or community members affected by the crime participate in the resolution of the matters arising from the crime, generally with the help of a facilitator (United Nations Office on Drugs and Crime (UNODC), 2006:6). Upon analysis of this definition, it is clear that the focus is on rectifying the harm done during a collaborative process, where every person involved plays a very important role in finding restitution for the victim. As far as restorative programmes are concerned, Batley (2008:27) is of the opinion that they could include victim support, victim awareness as well as life skills and mentoring for offenders. On their own these programmes could not always be seen as fully restorative. Programmes should, according to Batley, lead to the restoration of interpersonal relationships and/or intrapersonal psychosocial functioning that could also contribute to diminished recidivism. It can thus be said that all programmes that claim to be restorative in nature should include different restorative processes such as victim-offender mediation, peacemaking circles and family group conferences as part of the programme. 
According to the UNODC (2006:7-8), restorative justice programmes should include the following features:

- A flexible response to the circumstances of the crime, the offender and the victim, one that allows each case to be considered individually;

- A response to crime that respects the dignity and equality of each person, builds understanding and promotes social harmony through the healing of victims, offenders and communities;

- A viable alternative in many cases to the formal criminal justice system and its stigmatising effects on offenders;

- An approach that can be used in conjunction with traditional criminal justice processes and sanctions;

- An approach that incorporates problem solving and addressing the underlying causes of conflict;

- An approach that addresses the harms and needs of victims;

- An approach which encourages an offender to gain insight into the causes and effects of his or her behaviour and to take responsibility in a meaningful way;

- A flexible and variable approach which can be adapted to the circumstances, legal tradition, principles and underlying philosophies of established national criminal justice systems;

- An approach that is suitable for dealing with many different kinds of offences and offenders, including very serious offences;

- A response to crime which is particularly suitable for situations where juvenile offenders are involved and in which an important objective of the intervention is to teach the offenders some new values and skills;

- A response that recognises the role of the community as a prime site of preventing and responding to crime and social disorder.

The work done at the Centre reflects the abovementioned features of a restorative justice programme. For instance, each case at the Centre is managed individually and in a flexible way. An individual developmental plan is drawn up for each child that respects the dignity and equality of the child and is focused on the healing of the offender. To assist this healing, children are assigned to a specific probation officer. Probation staff attempt to develop a trusting relationship with these troubled children during their process of recovery. The vast range of diversion programmes used at the Centre provides viable alternatives to keep children out of the criminal justice system as long as possible. This will avoid the stigmatising effect for first-time offenders who enter the system, as they do not receive a criminal record. Diversion programmes are used in conjunction with the traditional criminal justice processes as children might still be prosecuted if they do not take responsibility for the crime or if they do not cooperate during the diversion programmes. At the Centre every child appears in court, even if the child is diverted, or will be diverted, to emphasise the seriousness of the situation. The diversion programmes focus on problem solving and addressing the underlying causes of the conflict as well as the acquisition of new values and skills (Figure 3). This is a very important part of the whole programme as this will lead to the transformation of the offender. During the diversion programme and the individual counselling offenders are helped to gain insight into the causes and effects of their behaviour and to take responsibility for their actions. Different 
kinds of offences and offenders are dealt with at the Centre. Children accused of very serious offences such as rape and murder are also referred to the Centre before their hearing in the regional courts. Unlike in the traditional criminal justice system, the personnel at the Centre focus on restoration and not retribution. The child-friendliness of the Centre and its staff makes it very suitable for working with juveniles. As some of the current programmes are community orientated and community driven, the community forms part of the process of rehabilitation and also takes part in the prevention of crime. The needs of victims of crimes are also addressed at the Centre, since some of the diversion programmes include activities such as victim-offender mediation. Although the activities at the Centre indicate that the Centre complies with all the features of a restorative justice programme, it is argued that they can improve on addressing the needs of the victims of the crimes. The details of the features of the restorative programmes at the Centre will become clearer in the course of the article.

\section{THE MAIN TASKS OF THE PROBATION STAFF IN PROMOTING RESTORATIVE JUSTICE}

In order to understand the tasks of the probation staff at the Centre, it is important to explain the whole practice model followed at the Centre. This will also put the work of the probation staff into perspective. It is not the aim of this article to explain the entire practice model in detail; however, special attention will be devoted to the probation staff as they are seen as the main role players in the implementation of restorative justice programmes.

The probation officer and the assistant probation officer have many different tasks. It isn't the aim of this article to give a comprehensive list of their tasks. However, this article will only explain the primary tasks of the probation staff in the practice model followed at the Centre (Figure 2).

\section{Assessment}

The probation officer and the assistant probation officer work as a team. The work of the team starts directly after a case docket has been opened. Upon the arrival of the child at the Centre, the members of the South African Police Services (SAPS) on duty will contact the assistant probation officer on stand-by. SAPS and an assistant probation officer are on duty on a 24-hour basis, including weekends and public holidays. The assistant probation officer will assess the juvenile, and the SAPS will contact the parents or guardian of the child. After a general screening, the assistant probation officer will recommend the release of the child to the investigating officer in appropriate instances. The investigating officer can release the child into the custody of the parents or guardian in case of minor offences after reporting the case to the probation officer at One Stop. Both will be warned to appear in court on the following court day. In the event of more serious crimes - normally schedule 2 offences such as murder, armed robbery or rape - the child will be detained in the holding facility situated next to the police reception area in the Centre.

Before the case goes to court for the preliminary enquiry, the probation officer will start with a developmental assessment. Usually this assessment is not entirely completed by the time the child goes to court, but after the completion of the preliminary enquiry this process will, depending on the outcome of the enquiry, be continued.

The assessment of the child is seen as very important as this forms the basis for further treatment of the child. A developmental assessment is done, which focuses on the child's strengths and abilities rather than the pathology attached to the offence or family environment from which the child comes (Sloth-Nielsen, 2006:19). This is very important, in our view, as it 
not only gives the probation officer a conceptual framework within which to work, but it provides a clear picture of the child. This assessment, if done correctly, also paves the way for the therapeutic intervention that is to follow. However, it seems that because of high caseloads the probation officers at the Centre do not currently use the developmental assessment as a therapeutic tool, but rather as an assessment framework. This could be attributed to the fact that not all of them are currently trained in the Circle of Courage model.

The Circle of Courage, first identified in Reclaiming Youth at Risk (Brendtro, Brokenleg \& Van Bockern, 1990), was adopted as the basic model of organising developmental assessment and strength-building interventions (Brendtro \& Larson, 2004:196). This model calls for the creation of opportunities for young people to experience belonging, mastery, independence and generosity (Brokenleg \& Van Bockern, 2003:23). These universal values provide the foundation for developing resilience and self-worth. If these strengths are developed, children thrive. However, various psychosocial risks disrupt personal development and produce conflict and despair. If a child is in conflict with the law, the Circle of Courage is broken, and therefore a developmental assessment is performed to determine the child's unique strengths and needs. A recommendation is made to the public prosecutor, based on the developmental assessment.

It is important to note that this pre-trial assessment is a move away from the traditional and historical task of the probation officer, namely to perform a social work investigation after conviction, for the purpose of preparing pre-sentence reports (Sloth-Nielsen, 2006:19).

\section{Recommendations to the public prosecutor}

The public prosecutor receives the docket with the charge and available affidavits from the police, as well as the assessments and recommendations by the assistant probation officer and probation officer. The public prosecutor is now in a position to decide whether s/he wants to withdraw the case or divert offences at his/her discretion. Except for petty crime, all other cases, irrespective of the offence, are referred to court for a preliminary inquiry (Du Plessis, 2009; Khokho, 2009).

The most important recommendations made by the probation officer include that the child be referred to a children's court, the appropriateness of diversion, possible release of the child into the care of a parent or appropriate adult, on his or her own recognisance, the detention and placement of the child, or that a further and more detailed assessment of the child is required (Child Justice Act section 40, 2008).

Gxubane (2008:12) is of the opinion that the probation officer should not only determine the strengths and needs of the child but should also determine who would be suitable service providers to render the necessary services to the particular child. Since the Act provides that the magistrate must determine the suitable diversion programme, it is important that the recommendations of the probation officer should include the most suitable programmes and the most suitable service providers.

\section{Preliminary enquiry}

The preliminary inquiry is a new concept developed in the Child Justice Act. A preliminary inquiry is an informal, inquisitorial, pre-trial procedure before an inquiring magistrate. It is furthermore compulsory for probation staff to attend the preliminary enquiry to give evidence when necessary, and to be updated with new information that appears during the enquiry. The team is in court every fourth week. This means that they have time to investigate cases thoroughly and for therapeutic interventions when not in court. Cycle time is thus also reduced 
as a probation officer is always at hand for investigation, during the preliminary enquiry and at the trial.

The main aim of the preliminary inquiry is to ensure that all the relevant information is available before decisions are taken and to ensure the child's access to diversion at the earliest possible opportunity. The preliminary enquiry is partially in line with the basic philosophy of restorative justice, since everyone involved with a crime gets an opportunity to voice their views before a decision is taken by the prosecutor and the court. It resembles the features of sentencing circles, where all those affected by an offence come together to decide on an appropriate sentencing plan which addresses the concerns of all participants, including the person harmed, the person who caused the harm, family and friends of each of these, other community members, and justice system representatives such as the magistrate, prosecutor, defence council, police officer and probation officer (Pranis, 2005:15). The preliminary enquiry cannot be seen as fully restorative in nature, since the prosecutor remains dominus litis to decide whether to prosecute or not, and the magistrate makes the final decisions regarding other matters such as detention or whether the proceedings should be referred to a children's court.

In attaining the objectives of the preliminary inquiry, the probation officer plays a very important role, since s/he has to make recommendations regarding diversion and diversion options, referrals of cases to children's court, and the availability of the information needed to make decisions (Child Justice Act 75, 2008). Since the probation officer is involved in the whole process, suitable diversion options could be identified early on in the process. This will pave the way for successful restoration, accepting responsibility, making restitution and avoiding recidivism.

\section{Therapeutic interventions}

The public prosecutor has to decide whether the child should be diverted or prosecuted. Should the decision be to refer a child for diversion, the case is remanded for a period of at least six weeks, during which an appropriate programme must be completed. The probation officer will use the developmental assessment to draw up a suitable developmental plan that would contribute to the restoration of the youth offender.

On the return date the prosecutor will, depending on the report of the probation officer, either withdraw the case or remand the case for completion of the diversion programme, or remand the case for trial if the child did not cooperate during the diversion programme and therapeutic interventions by the probation officer. It might become clear during the diversion programme and therapeutic interventions that the child might benefit from an additional diversion programme or more therapy. Depending on the cooperation of the child, the case might be withdrawn before completion of all the prescribed programmes and therapy.

Currently the nature and contents of the programme in which a child is placed, as well as the institution that will render the programme, are to be determined entirely by the probation officer after completing the developmental assessment. However, this position will change when the Act comes into operation. At that point the presiding officer will determine the programmes after proper recommendations by the probation officer (Du Plessis, 2009).

The probation officer will, as part of the developmental assessment, determine if the family of the child is in need of services. This takes place irrespective of the criminal proceedings. Even if the case is withdrawn, the services rendered by a probation officer to the family and the juvenile are unaffected. The last phase of the practice model consists of the aftercare and monitoring of all the children that complete the programmes. The application of restorative 
justice principles during interventions will be discussed as part of diversion services rendered to children.

\section{Sentencing}

If a child was not diverted or did not cooperate during the diversion process and was subsequently tried and found guilty, the probation officer will conduct an investigation for a pre-sentencing report. It is possible to include restorative justice in the sentencing phase. However, no evidence of the application of restorative justice was found in this phase.

\section{DIVERSION SERVICES RENDERED TO THE CHILD IN CONFLICT WITH THE LAW}

According to the National Prosecuting Authority (NPA) (2008), there is an increased focus on diversion. According to the annual reports of the NPA, diversions increased by $213.8 \%$ from 17952 to 46470 since 2003/04 until 2007/08. Although they do not distinguish between adult and child diversions, it is evident that diversion plays an increasingly important part in the South African criminal justice system. According to Swanson-Jacobs (2007), it was recorded that during the 2006/07 financial year until May 2007 that a total of 21882 children were placed in diversion programmes. This is in line with the evidence before the Parliamentary Monitoring Group (2008) that on average 1571 children are diverted every month. With the increased number of diversions, the potential for applying restorative justice practices has also increased significantly.

According to Zehr (2002:44), three distinct models tend to dominate the practice of restorative justice, namely victim-offender conferences, family group conferences and circle approaches. Each of these models involves an encounter between stakeholders, the victim and the offender at minimum (in some cases the community and justice people are also included). If the victim and offender for one reason or another cannot face one another directly, or it is inappropriate, letters and/or videos are used in preparation for, or in the place of, a direct meeting. What is important to note is that all of these models involve some form of a meeting. During these encounters an opportunity is provided for the wrongdoing to be articulated by victims and acknowledged by offenders. Outcomes focus on restitution and/or apology. It is also important to discuss questions such as "Will the offender do this again?", "How will they live together in the same community?" and "How do they move on with life?". The participation of all the stakeholders should be voluntary and the offender should acknowledge his/her responsibility (Zehr, 2002:44-46). The question could be asked as to how restorative justice is applied in South Africa and, more specifically, at the Centre?

The increased application of restorative justice practices has influenced the content of diversion programmes, since programmes have started to focus more on repairing the harm caused by crime. Processes such as family group conferences, group conferences, sentencing circles and victim-offender mediation have been introduced. In some instances these processes form part of diversion programmes. This promotes more humanitarian and less stigmatising responses to child offending and victim-offender mediation (Wood, 2003:1). This also correlates with the aims of $\underline{u}$ buntu.

Diversion is a very important part of the Act and aims to divert children who committed a crime away from formal criminal proceedings into crime-prevention and reintegration programmes. Adding to this, Wood (2003:3) is of the opinion that one of the central objectives of the new child justice system is to promote the expanded use of diversion in a consistent and just manner. In 2001 the National Directorate of Public Prosecutions estimated that prosecutors 
were diverting more than 30000 children per annum away from criminal trials to a range of available programmes around the country. A large number of these kids are charged with minor offences such as petty theft, minor assaults and damage to property.

\section{FIGURE 2 \\ AN ILLUSTRATION OF THE ONE-STOP CHILD JUSTICE CENTRE MODEL OF PRACTICE}

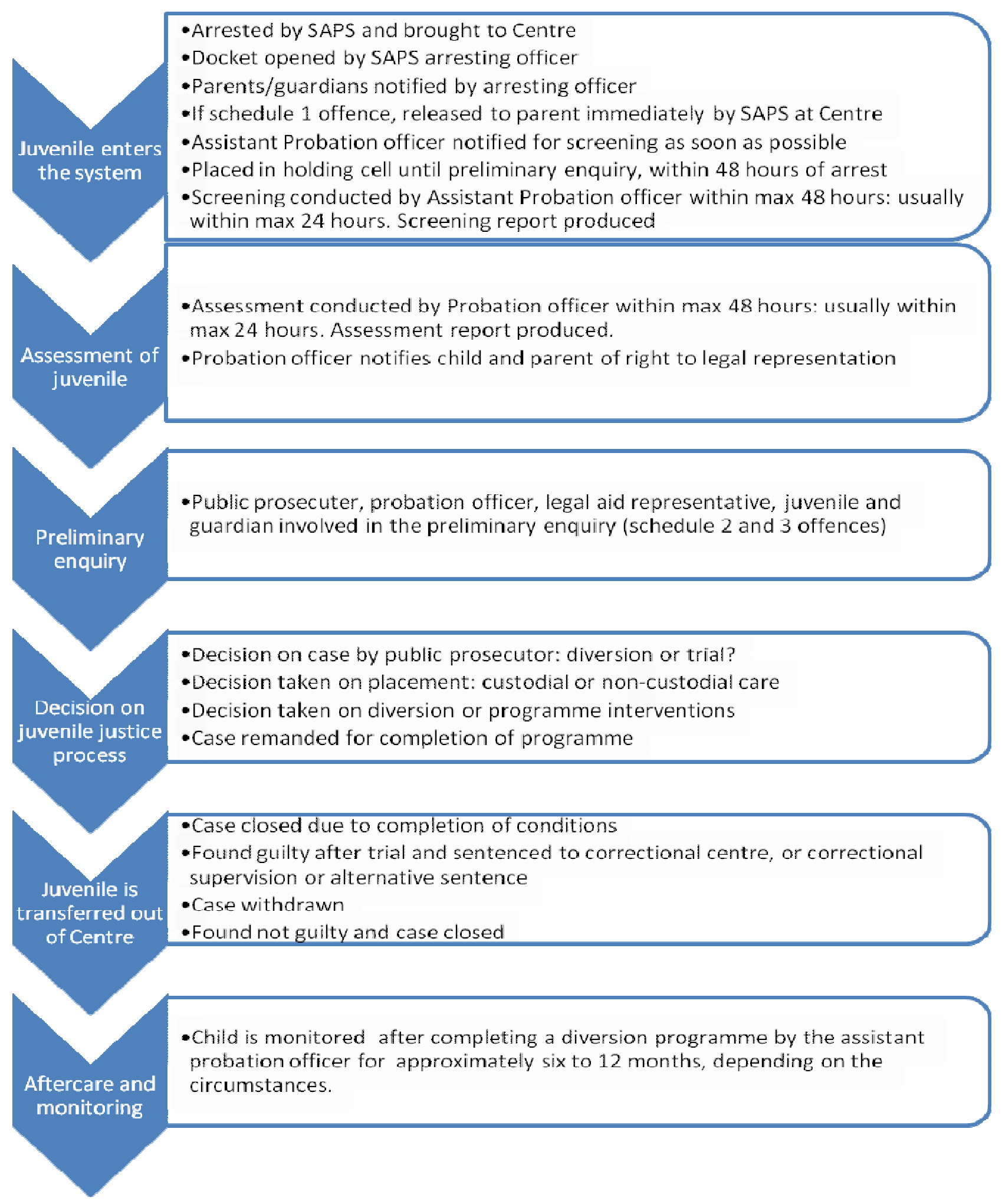

Social Work/Maatskaplike Werk 2010:46(3) 
Data showed that the typical diversion candidate is black, 16 to 17 years old, and in trouble for shoplifting or for theft of goods valued at less than R100 (Woodward, Sloth-Nielson \& Mathiti, 2008:70). Consequently it would be common sense to keep these children away from real criminals and rather place them in programmes where they will be helped to understand that what they did was wrong, develop their emotional intelligence so that they can understand their own feelings and those of the victim, and to give them the necessary life skills in order not to re-offend. Attending to these children in diversion programmes should be a consistent and just process.

Diversion does not necessarily require a child to be placed in a formal programme, but includes interventions such as receiving a police caution, writing a letter of apology, participating in an alternative dispute resolution forum or being placed under supervision (Wood, 2003:1). Diversion into a formal programme usually takes effect after the preliminary enquiry (Figure 2). According to article 51 of the Act ( 75 of 2008), the objectives of diversion are:

- to deal with a child outside the formal crime justice system in appropriate cases;

- to encourage the child to be accountable for the harm caused by him or her;

- to meet the particular needs of the individual child;

- to promote the reintegration of the child into the family and community;

- to provide an opportunity to those affected by the harm to express their views on the impact on them;

- to encourage rendering to the victim some symbolic benefit or the delivery of some object as compensation for the harm;

- to promote reconciliation between the child and the person or community affected by the harm caused by the child;

- to prevent stigmatising the child and prevent the adverse consequences flowing from being subject to the criminal justice system;

- to reduce the potential for re-offending;

- to prevent the child from having a criminal record; and

- to promote the dignity and well-being of the child, and the development of his or her sense of self-worth and ability to contribute to society.

It is thus clear that diversion is in essence based on the philosophy of restorative justice, but it also has a clear focus on the prevention of further crime and the reintegration of the offender into society. According to the UNODC (2006:9-11), the objectives of restorative justice should be that there is a focus on support to the victim, repairing damaged relationships, using consensus as part of the process of deciding how to repair the harm done, denouncing criminal behaviour as unacceptable, encouraging the taking of responsibility by every stakeholder involved, reduction of recidivism by, amongst other things, facilitating reintegration into the community, and lastly, to identify factors that lead to crime and work on crime prevention strategies. The work done by the Centre corresponds with most of these objectives and they receive attention during the entire process followed, but especially during diversion. It can thus be said that diversion forms one of the cornerstones of restorative justice at the Centre.

In the early days of the development of restorative justice it was common for a wide range of programmes for child offenders to be considered as restorative, because the main aim was to find an alternative to the criminal justice system and to give children an opportunity to change 
their behaviour and consequently to avoid a criminal record. However, in recent years scholars in this field have become increasingly concerned about what they see as a "bandwagon" approach to restorative justice. It is argued that not all diversion programmes are restorative in nature. Practitioners of restorative justice practices therefore prefer to refer to a continuum of restorative justice. On this continuum of restorative justice the scales vary from programmes being fully restorative, on the one end of the scale, to pseudo- or non-restorative, on the other end (Skelton \& Batley, 2006:7; Zehr, 2002:54-55).

Zehr (2002:54-57) holds that when assessing the degree of "restorativeness", the following six questions should be asked to analyse both the effectiveness and the extent of restorative justice models for a particular situation:

- Does it address harms and causes?

- Is it victim-orientated?

- Are offenders encouraged to take responsibility?

- Are all three stakeholder groups involved?

- Is there an opportunity for dialogue and participatory decision-making?

- Is it respectful to all parties?

In using these questions it becomes clear that an encounter such as a circle may be fully restorative, whereas a particular diversion programme might only be partially or mostly restorative in nature.

The Centre has an array of possible diversion programmes that they could send the children to participate in (Figure 3). At this point it should also be mentioned that some of the children who attend the diversion programmes are not formally sent to the diversion programme by the court. Children with uncontrollable behaviour are in some cases reported to the Centre by schools and parents. They are then assessed and motivated to attend a programme to help them cope with their problems, before they come into formal conflict with the law. Some of these programmes are facilitated by the staff of the Centre under the auspices of the Department of Social Development, while others are out-sourced. NICRO is one of the main service providers of diversion programmes for the Centre. This organisation was established in September 1910 and has expanded over the years to become a very important role player in the fight against crime nationally. NICRO's projects encourage offenders to take responsibility for their actions, provide support to victims of crime, help with the development of small enterprises, and promote constructive instead of destructive lifestyles. The four pillars of their service delivery focus on offender reintegration, community victim support, diversion and youth development, and economic opportunities (Steyn, 2005:51-52). NICRO is seen as one of the leaders in the field of diversion, as the organisation piloted diversion in 1992 (Swanson-Jacobs, 2007). Because of the increase in the number of children being diverted, it became necessary to develop proper norms and standards for diversion programmes to ensure that these children were attended to professionally and respectfully. On 13 July 2007 Dr Jean Swanson-Jacobs, the then Deputy Minister for Social Development, unveiled the minimum norms and standards booklet on diversion at the Centre in Bloemfontein (Department of Social Development, 2007).

Apart from the programmes listed in Figure 3, there are also community-based programmes available. These programmes are presented in the communities. The Life Solutions and Motswedi programmes are hosted by NGOs and volunteers. As these programmes are presented in the communities, it is easy for the children to attend and the community takes 
some of the responsibility in transforming children in conflict with the law. When problems are experienced with children in need of alcohol and drug rehabilitation, the services of the South African National Council on Alcoholism and Drug Dependence (SANCA) are used. Presently there are only limited placements available at the Aurora alcohol and drug centre. This Centre is in the process of developing a youth centre that will provide special programmes to children with dependency problems.

\section{FIGURE 3}

\section{DIVERSION OPTIONS AVAILABLE AT THE CENTRE}

Department of Social Development (DoSD) Children under 15 years
NICRO - Older children, usually above 15 years
- Responsible sexual behaviour programme suitable for sexual offenders, includes sessions on sexual behaviour, self-esteem, sexual relationships and includes individual sessions over a 10-week period and a 3-day outdoor program

- Take a lead in life (responsible decision -making) a leadership programme that includes life skills

- From scars to stars - focusses on responsible decision-making and problem-solving offered on a group basis

- Victim offender mediation

- Family group conferencing

- Torro outdoor programme - a 3-day outdoor activity-based programme which includes life skills, therapy also included

- Community service

- Seyakula - life skills, offered to children in the Rocklands area

- Parenting skills over a weekend (2 days)

- Yes programme - 3 days

- Journey programme

- Pre-trial community service

- Family group conference

- Positive parenting

- Individual sessions if needed

- Victim offender mediation if needed

- Life solutions programme - 10-week programme, meet three times a week, includes basis and creative skills development - offered for children in Heidedal and Heatherdale areas

- Motswedi programme- children in Bainsvlei area

Welfare services of the Dutch-Reformed church (church based in a specific community)

SANCA or drug rehabilitation facilities
- Substance abuse rehabilitation - limited placements in drug facility 
Currently juveniles have to render community services at schools, libraries, the SPCA, NICRO (in the form of office work), local clinics and at the Centre, as well as working with the disabled. Attempts are made to place the juveniles in a facility which will benefit them and where mentoring will take place. There should also be effective supervision by a trustworthy adult. The focus should be on restoration, reintegration and prevention of further crime rather than punishment. Despite the laudable intentions of the Centre to include community service in its programmes, it became apparent during the evaluation that community service is seen as punishment by the juveniles and their parents. This misperception could be addressed by the introduction of more restorative circles such as the sentencing circles described by Pranis (2005:15). This will ensure that the child and the parent perceive community service as a way of putting right the wrong, and not as punishment.

\section{EVALUATING THE RESTORATIVENESS OF THE DIVERSION PROGRAMMES}

In order to assess the restorativeness of these programmes, the six questions posed by Zehr (2002:54-57) could be used to evaluate the different programmes offered in the diversion programmes (see point 5). If the programme complies with the particular requirement, it scores one point (-)); if the programme does not comply with the requirement, no points are awarded (:); and when it is only partially met, it scores half a point $(:)$ ). A programme can thus score a maximum of six points. This system was then integrated with Zehr's (2002:55) continuum, which identifies certain degrees of restorative justice practices. Although Zehr's continuum does not quantify the restorativeness of a programme, we aimed to do so (Figure 3).

\section{FIGURE 4}

\section{DEGREES OF RESTORATIVE JUSTICE PRACTICES: A CONTINUUM}

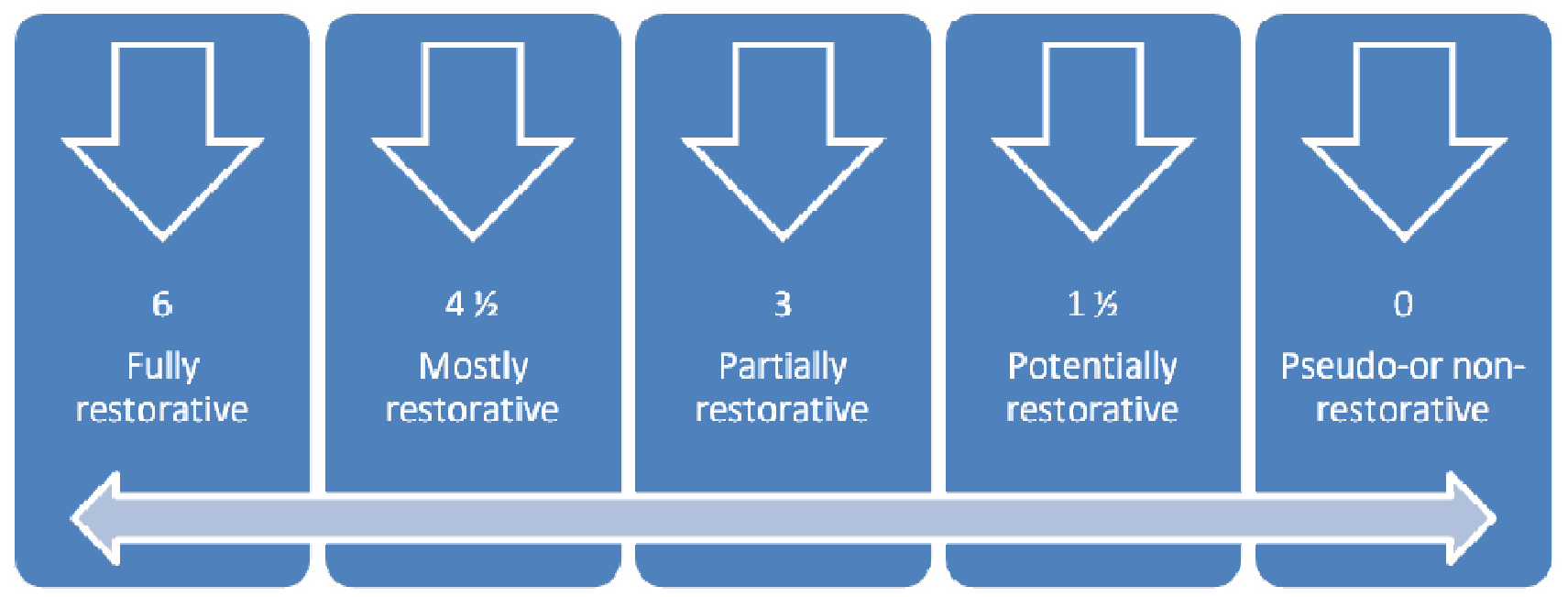

(Zehr, 2002:55, adapted)

It is clear from the table that not all the diversion programmes are fully restorative in nature. It could be said that most $(70.5 \%)$ of the programmes are between partially and mostly restorative ( $3 \frac{1}{2} 2$ points). It is furthermore clear that none of the programmes has been evaluated as pseudoor non-restorative (0 points). Only four programmes $(23.5 \%)$ are fully restorative in nature. Victim offender-mediation and family group conferencing, which can be seen as fully restorative (6 points), are available options for diversion. Unfortunately, only six out of a total of 590 cases (less than one percent) which were withdrawn after the successful completion of a diversion programme attended these fully restorative programmes (Table 4). The lack of victim orientation and the involvement of all the groups in the process are regarded as deficiencies in the service delivery. It would seem that, generally speaking, the victim is not included in the 
restorative processes used. It could thus be said that, although the Centre has a philosophy of restorative justice, most of their programmes are not fully restorative in nature.

TABLE 1

OUTLINE OF RESTORATIVENESS OF DIVERSION PROGRAMMES AVAILABLE TO THE CENTRE

\begin{tabular}{|c|c|c|c|c|c|c|c|}
\hline \multirow[b]{2}{*}{$\begin{array}{l}\text { Programmes } \\
\text { available at the } \\
\text { Centre }\end{array}$} & \multicolumn{6}{|c|}{$\begin{array}{l}\text { Zehr's criteria for the assessment of the restorativeness of the } \\
\text { programmes of the Centre }\end{array}$} & \multirow[b]{2}{*}{$\begin{array}{l}\text { Result out } \\
\text { of six } \\
\text { questions } \\
\text { posed }\end{array}$} \\
\hline & $\begin{array}{c}\text { Harms \& } \\
\text { causes? }\end{array}$ & $\begin{array}{l}\text { Victim } \\
\text { orienta- } \\
\text { ted? }\end{array}$ & $\begin{array}{l}\text { Offender } \\
\text { takes re- } \\
\text { sponsibi- } \\
\text { lity? }\end{array}$ & \begin{tabular}{|l} 
All three \\
groups \\
in- \\
volved?
\end{tabular} & $\begin{array}{c}\text { Dialogue \& } \\
\text { participative } \\
\text { decision- } \\
\text { making? }\end{array}$ & \begin{tabular}{|} 
Respectful \\
to all \\
parties?
\end{tabular} & \\
\hline $\begin{array}{l}\text { Responsible sexual } \\
\text { behaviour } \\
\text { programme }\end{array}$ & (:) & :2: & (:) & (2) & ;) & (:) & $31 / 2$ \\
\hline Take a lead in life & ;:) & :(2) & ;) & : & ;) & (:) & $31 / 2$ \\
\hline From scars to stars & (:) & (2) & (:) & (2) & :-) & (:) & $31 / 2$ \\
\hline $\begin{array}{l}\text { Victim-offender } \\
\text { mediation }\end{array}$ & ;) & ;) & ;) & (:) & (:) & (:) & 6 \\
\hline $\begin{array}{l}\text { Family group } \\
\text { conferencing }\end{array}$ & (:) & (:) & (); & (2) & (2) & (:) & 6 \\
\hline $\begin{array}{l}\text { Torro outdoor } \\
\text { programme }\end{array}$ & (:) & : : & ;) & : : & :- & (:) & $31 / 2$ \\
\hline $\begin{array}{l}\text { Community } \\
\text { service }\end{array}$ & (:) & (2) & (:) & (2) & ;) & (:) & $31 / 2$ \\
\hline Seyakula & (:) & (:) & (:) & (2) & ;) & (:) & $31 / 2$ \\
\hline Yes programme & (:) & (2) & (:) & (2) & ;) & (:) & $31 / 2$ \\
\hline $\begin{array}{l}\text { Journey } \\
\text { programme }\end{array}$ & (:) & (2) & (:) & (2) & ; & (;) & $31 / 2$ \\
\hline $\begin{array}{l}\text { Pre-trial commu- } \\
\text { nity service }\end{array}$ & (:) & (2) & (:) & (2) & ;) & (:) & $31 / 2$ \\
\hline $\begin{array}{l}\text { Family group } \\
\text { conference }\end{array}$ & (:) & (:) & ;: & (:) & (:) & (:) & 6 \\
\hline $\begin{array}{l}\text { Individual sessions } \\
\text { if needed }\end{array}$ & (:) & (2) & (:) & (2) & (2) & (:) & 4 \\
\hline $\begin{array}{l}\text { Victim-offender } \\
\text { mediation }\end{array}$ & (:) & (:) & (:) & (:) & (:) & (:) & 6 \\
\hline $\begin{array}{l}\text { Life solutions } \\
\text { programme }\end{array}$ & (:) & (2) & (:) & (2) & :-) & (:) & $31 / 2$ \\
\hline Motswedi & (:) & (2) & (:) & (2) & ;) & (2) & $31 / 2$ \\
\hline $\begin{array}{l}\text { Substance abuse } \\
\text { rehabilitation }\end{array}$ & (:) & : & (:) & : : & :) & (:) & $31 / 2$ \\
\hline
\end{tabular}

As many of the crimes are petty in nature, such as shoplifting, it is acknowledged that it is not always necessary or feasible to include the victim and consequently be fully restorative. However, there are also crimes that are more suitable for including the victim in the restorative process, such as theft with a substantial rand value, robbery and assault cases. Perhaps it is not necessary that all the programmes are fully restorative, as there is a place for partially to mostly 
restorative programmes. However, it should be noted that the currently fully restorative programmes should be used more regularly. According to Du Plessis (2009), some of the probation and assistant probation officers are trained in conferencing. He finds it very difficult to motivate the staff at the Centre to use this technique as they feel that it takes too much of their time and that their caseloads are too high (Table 2; Figures $4 \& 5$ ). The therapeutic staff body at the Centre in Bloemfontein currently consists of a chief probation officer, five probation officers and five assistant probation officers. The staff responsible for services in the rural areas include a chief probation officer, three probation officers and three assistant probation officers. According to Du Plessis (2009), the caseload of the rural area is on average between 30 to 40 cases per month and they are more focused on prevention services than on diversion. In total there are also 21 volunteers available in the Bloemfontein and rural areas. It may thus be deduced that there are not enough staff members available to work fully restoratively in all cases, but victim panels, for example, could be used for the less serious offences where victims of crime come and tell the offenders about the consequences of the crime for them, etc.

\section{TABLE 2}

\section{MAIN DIVERSION PROGRAMMES ATTENDED BY YOUTHS BEFORE CASES WERE SUCCESSFULLY WITHDRAWN IN THE MOTHEO DISTRICT ${ }^{2}$ IN 2008}

\begin{tabular}{|c|c|c|c|c|c|c|c|c|}
\hline & $\begin{array}{l}\text { Family } \\
\text { group con- } \\
\text { ference }\end{array}$ & \begin{tabular}{|c|} 
Victim- \\
offender \\
confe- \\
rencing
\end{tabular} & $\begin{array}{l}\text { Pre-trial } \\
\text { commu- } \\
\text { nity } \\
\text { service }\end{array}$ & $\begin{array}{c}\text { Sexual } \\
\text { offences } \\
\text { program- } \\
\text { me }\end{array}$ & $\begin{array}{l}\text { Life skills } \\
\text { program- } \\
\text { me }\end{array}$ & $\begin{array}{l}\text { Youth } \\
\text { empower- } \\
\text { ment }\end{array}$ & $\begin{array}{c}\text { Individual } \\
\text { sessions and } \\
\text { programmes }^{3}\end{array}$ & $\begin{array}{l}\text { Total cases } \\
\text { successfully } \\
\text { withdrawn }\end{array}$ \\
\hline Jan & & & 2 & 6 & & 8 & 56 & 72 \\
\hline Feb & & & & 10 & 11 & & 40 & 61 \\
\hline Mar & & & & 3 & 8 & 8 & 31 & 50 \\
\hline Apr & 1 & 1 & 1 & 1 & & & 46 & 50 \\
\hline May & & & & & & & 48 & 48 \\
\hline Jun & & & 6 & & & 10 & 40 & 56 \\
\hline Jul & & & 2 & & & & 33 & 35 \\
\hline Aug & & & 2 & & 10 & 5 & 36 & 53 \\
\hline Sept & & & 2 & 1 & & & 22 & 25 \\
\hline Oct & 2 & 2 & 3 & 5 & 25 & & 20 & 57 \\
\hline Nov & & & 4 & 3 & 4 & & 24 & 35 \\
\hline Dec & & & 8 & & & 10 & 30 & 48 \\
\hline Total & 3 & 3 & 30 & 29 & 58 & 41 & 426 & 590 \\
\hline
\end{tabular}

\footnotetext{
2 The Motheo district includes Bloemfontein and the surrounding rural areas. Separate statistics for the Mangaung One-Stop Centre are not available.

${ }^{3}$ This includes the attendance of programmes such as Take a lead in life, From Scars to Stars, Torro Outdoor Programme, and the community-based diversion programme.
} 
FIGURE 5

CHILDREN ASSESSED, REFERRALS TO DIVERSION AND SUCCESSFUL DIVERSIONS IN THE MOTHEO DISTRICT IN 2008



Therapeutic staff have a very high caseload to manage. In 20081306 assessments were done, 791 new children were diverted and 590 children had to be monitored for an additional six months - a huge task for 18 professionals (Figure 5). Figure 6 shows that the diversion caseload of the probation staff varies from month to month. In 2008 the caseload was the lowest in March, with 42 cases, and the highest in June, with 302. On average the diversion caseload for 2008 was 144.4 cases per month. It should be taken into account that children are not assigned to a single programme, but rather that an interventionist stance is taken which makes use of an integrated range of interventions to address the overall needs of the child, based on the assessments made by the probation officer. These programmes are supplemented by continuous individual contact and group work with the child by the probation officer, while the child is attending a specific diversion programme. These programmes are usually presented by assistant probation officers and/or volunteers. This is seen as a very good method to ensure low recidivism rates, as the child receives a variety of interventions. This probably also contributes to improvements in the success of the diversion programmes. The main aim of these interventions is to support the child until the desired outcome is achieved. After the withdrawal of the case on completion of diversion, the child is monitored by the assistant probation officer for another six months. This monitoring is also seen as contributing to the effectiveness of the diversion programmes as problems that might arise after completion could be attended to quickly. 
FIGURE 6

DIVERSION CASELOAD PER MONTH FOR 2008

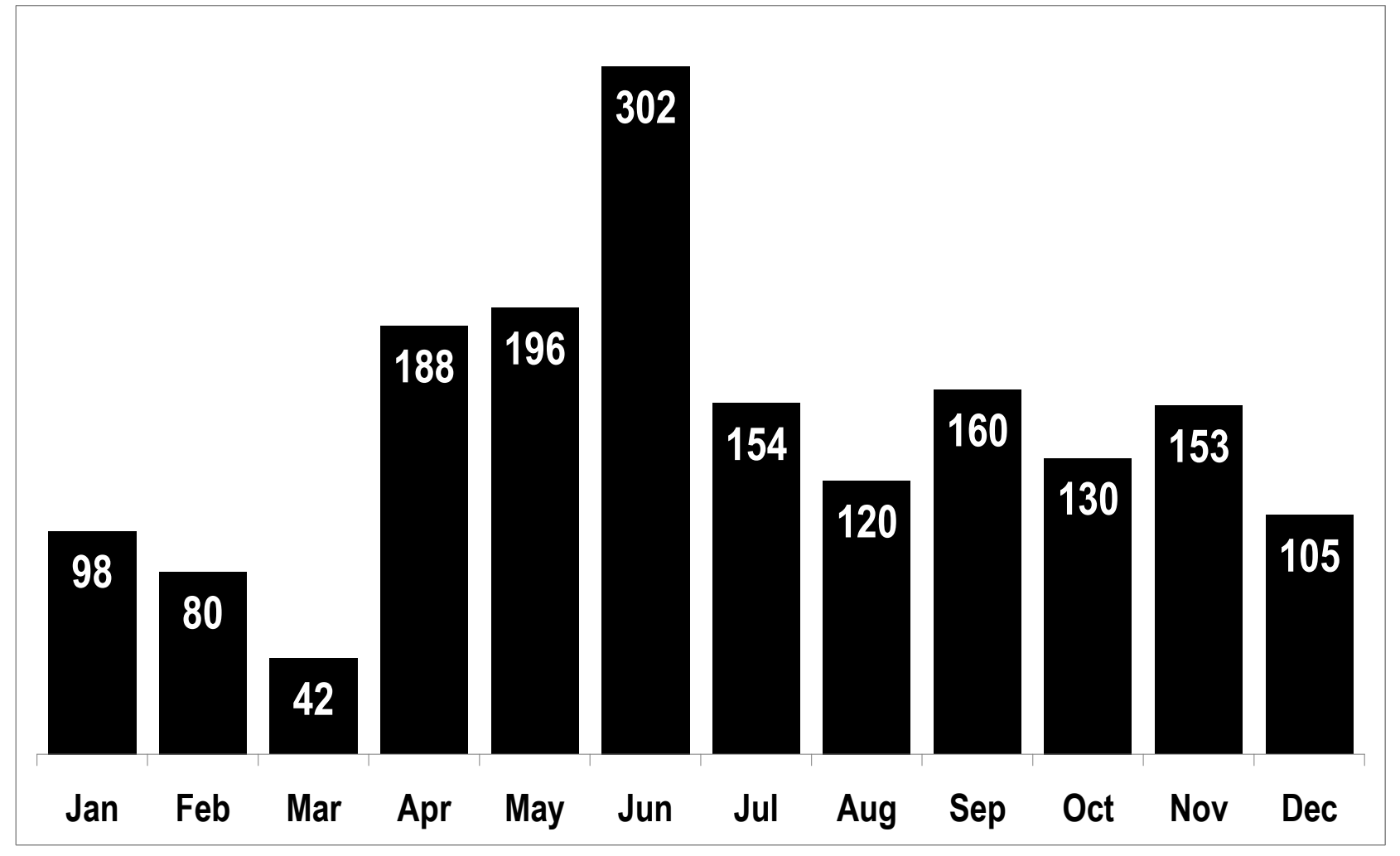

\section{CHALLENGES AND RECOMMENDATIONS}

The most common challenges that the probation staff experience are the high caseloads, children not attending counselling sessions and diversion programmes, and parents not taking responsibility to help their children, especially the uncontrollable children who are referred to the Centre. The staff also experience that the parents of most of the children as uncooperative and that they do not motivate the children to participate in the programmes. In many cases they also do not attend the parenting programmes. It is suggested that the increased use of restorative practices, such as different types of peacemaking circles and family group conferences, could contribute to changing the attitude of the parents and getting them involved in the lives of their children. Parents should be included in the programme/process and receive training in general parenting skills. They should also be motivated to take responsibility for the development and transformation of the child.

From an eco-systemic perspective, the whole family needs to be involved in the process of diversion in order to effectively help the child. All the stakeholders in the child's ecology should be involved when developing programmes. The community, church and the school should also be engaged. The school and church could be used in order to prevent crime and general behavioural problems. Participation of all these systems could also help to build resilient, happy children (Brendtro \& Larson, 2006:33-40).

Another problem created by the parents of children who have committed a crime is that they do not want the child back at home, sometimes even with first offenders. This makes it very difficult for probation officers as the children then have to be placed in foster care, with children's court procedures having to be initiated. Foster care placements are limited and this 
creates additional professional services that are not really focused on crime and crime prevention.

The uncontrollable children who are referred to the Centre have not yet committed an offence; therefore nothing can be done to force the children and their parents to cooperate. They also attend the diversion programmes. If they do not attend these programmes on a regular basis, it could negatively affect the outcomes of the programmes, as they could influence the motivation of the children who were formally diverted to the programme. Prevention services could also be negatively affected.

It was further identified that the staff need more training, especially in restorative processes. The in-house training is excellent, but staff will benefit from more specialised training. In future probation work will be seen as a field of specialisation that will necessitate registration with the Council for Social Service Professions (Du Plessis, 2009).

It was indicated that there are many programmes available to which children could be diverted. Criticism is that the diversion programmes are general in nature and not always sufficiently specific in order to help children with specific needs. Long-term programmes that focus on alcohol and drug abuse, aggression, interpersonal violence and sexual violence, trauma and dealing with these traumatic events, as well as skills development programmes, could be useful. These programmes should also have a very clear theoretical foundation from which they are developed.

The impact of the interventions by the probation staff in the diversion programmes is still unclear, as no well-conducted research data are available on the long-term results of the programmes. The current programmes have to be scientifically scrutinised and researched in order to determine their actual impact on the community and the child. It is recommended that this be done in order to improve the programmes where necessary. It was also indicated that the programmes are not always fully restorative. It is further recommended that an attempt should be made, where applicable, to increase the restorativeness of programmes.

It is very difficult to work with children in conflict with the law as many of them commit crimes because of personal and family problems, and helping them to cope with these problems is not easy. They need intensive therapeutic help. The question arises as to whether the assistant probation officers and in some cases volunteers, who are primarily responsible for the group sessions in the diversion programmes, are properly qualified to work effectively with these children? When working restoratively, especially when performing family group conferences, victim-offender mediation, circles and therapeutic groups, properly trained staff are needed. These people should also receive supervision of a high quality. The minimum norms and standards for diversion indicate generic and additional knowledge and skills for all facilitators (Department of Social Development, 2007:16-19). These should be used in order to determine if all the role players who take part in programmes are qualified to work as facilitators in diversion programmes.

\section{CONCLUSION}

This article explored the work of the probation staff at the Mangaung One-Stop Child Justice Centre and, more specifically, the foundations of restorative justice and its implementation by the probation staff. The main foundations of restorative justice were illustrated and its execution described and evaluated. The primary findings of this research show that the main tasks of the probation staff are to focus on the assessment of the child, to make appropriate 
recommendations to the public prosecutor, to give evidence and up-to-date information on the child at the preliminary enquiry, and lastly but very importantly, to deliver therapeutic interventions of which casework and the diversion programmes are the most important.

It was further explained how the increased application of restorative justice practices influenced the content of diversion programmes, since programmes have started to focus more on repairing the harm caused by crime. Sadly, it was found that the programmes currently used at the Centre are not fully restorative in nature. Processes such as family group conferences, group conferences, sentencing circles and victim-offender mediation are available, but are not regularly used.

Special attention was also given to diversion, as this is a very important part of the Child Justice Act (75 of 2008) and aims to divert children who committed a crime away from formal criminal proceedings into crime-prevention and reintegration programmes. It was identified that these programmes are in need of scientific appraisal and research to determine their actual impact on the community and the child. Not all of them are also fully restorative in nature, although this is not necessarily a problem.

In general it was found that the Mangaung One-Stop Child Justice Centre delivers a very good service to children in conflict with the law and the community at large. The different diversion programmes also cater for a range of needs, although more programmes are needed that will cater for specific problems such as anger management and alcohol and drug abuse. Lastly, some of the most pressing challenges experienced at the Centre were identified and some recommendations were made.

\section{REFERENCES}

ACTS see SOUTH AFRICA

BATLEY, M. 2008. The value of restorative justice to the reintegration of offenders. SA Crime Quarterly, 26:27-34.

BRENDTRO, L., BROKENLEG, M. \& VAN BOCKERN, S. 1990. Reclaiming youth at risk: our hopes for the future. Bloomington, IN: National Educational Service.

BRENDTRO, L.K. \& LARSON, S.J. 2004. The Resilience Code: finding greatness in youth. Reclaiming Children and Youth, 12(4):194-200.

BRENDTRO, L.K. \& LARSON, S.J. 2006. The resilience revolution. Solution tree: Bloomington, IN: National Educational Service.

BROKENLEG, M. \& VAN BOCKERN, S. 2003. The science of raising courageous kids. Reclaiming Children and Youth, 12(1):22-27.

BROODRYK, J. 2002. Ubuntu life lessons from Africa. Pretoria: Ubuntu School of Philosophy.

CHILD JUSTICE ACT, 75 of 2008 see SOUTH AFRICA

DEPARTMENT OF SOCIAL DEVELOPMENT. 2007. Minimum norms and standards for diversion. Pretoria: Government Printers.

DEPARTMENT OF WELFARE. 1997. The White Paper for Social Welfare. General notice 1108 of 1997. Pretoria: Government printers. 
DU PLESSIS, R.J. 2009. Personal interview. Chief probation officer at One Stop Child Justice Centre. Bloemfontein.

FOUCHÉ, C.B. 2007. Qualitative research designs. In: DE VOS, A.S., STRYDOM, H., FOUCHÉ, C.B. \& DELPORT, C.S.L. (eds) Research at grass roots: for the social sciences and human service professions. Pretoria: Van Schaik Publishers.

GAllineti, J., KASSAN, D. \& EHLERS, L. 2006. Child Justice in South Africa: children's rights under construction. Conference report. The Open Society Foundation for South Africa, Newlands.

GXUBANE, T. 2008. Agents of restorative justice? Probation officers in the child justice system. SA Crime Quarterly. 25:11-16.

HODGKIN, R. \& NEWELL, P. 2007. Implementation handbook for the convention on the rights of the child. Switzerland: United Nations Publications.

KHOKHO, V. 2009. Personal interview. Advanced district public prosecutor at One Stop Child Justice Centre. Bloemfontein.

LAWS see SOUTH AFRICA

McCOLD, P. 2006. The recent history of restorative justice. In: SULLIVAN, D. \& TIFFT, L. (eds) Handbook of restorative justice: a global perspective. New York: Routledge.

NATIONAL PROSECUTING AUTHORITY (NPA). 2008. Annual report. [Online] Available: http://www.npa.gov.za/UploadedFiles/Annual\%20Report\%202007-08\%20Section\%201-3.pdf.

[Accessed: 28/07/2009].

MORRISON, B. 2007. Restoring safe school communities. Sydney: Federation Press.

PARLIAMENTARY MONITORING GROUP. 2008. Child Justice Bill [B49-2002]:

Department summary of submissions. [Online] Available: http://www.childjustice.org.za/ parl_reports/2008Mar12.pdf. [Accessed: 28/07/2009].

PATTON, M.Q. 2002. Qualitative research and evaluation methods $\left(3^{\text {rd }}\right.$ ed). Thousand Oaks, CA: Sage Publications.

PRANIS, K. 2005. The little book of circle processes. Good Books: Intercourse, PA.

POOVAN, N., DU TOIT, M.K. \& ENGELBRECHT, A.S. 2006. The effect of the social value of ubuntu on team effectiveness. South African Journal of Business Management, 37(3):1727.

SCHOEMAN, L. 2009. Personal interview. Magistrate at One Stop Child Justice Centre. Bloemfontein.

SKELTON, A. \& BATLEY, M. 2006. Charting progress, mapping the future: restorative justice in South Africa. Pretoria: Restorative Justice Centre.

SLOTH-NIELSEN, J. 2006. A short history of time. Charting the contribution of social development service delivery to enhance child justice 1996-2006. In: GALLINETTI, J., KASSAN, D. \& EHLERS, L. Child justice in South Africa: children's rights under construction. Conference report. Newlands: Open Society Foundation of South Africa.

SOUTH AFRICA. 2008. Child Justice Act, 75 of 2008. Pretoria: Government Printers. 
SWANSON-JACOBS, J. 2007. Speech by the Deputy Minister of Social Development, during the launch of the Minimum Norms and Standards booklet on Diversion in Bloemfontein. [Online] Available: http://www.search.gov.za/info/previewDocument.jsp?dk=\%Fdata\%2 Fstatic\%2Finfo\%2Fspeeches\%2F2007\%2F07071312451002.htm\%40Gov\&q= (+stream-lining $+) \& \mathrm{t}=\mathrm{J}+$ Swanson-Jacobs $\% 3 \mathrm{~A}+\mathrm{Launch}+\mathrm{of}+$ Minimum+Norms+and+Standards+booklet+on+ Diversion. [Accessed: 02/05/2009].

STEYN, F. 2005. Review of South African innovations in diversion and reintegration of youth at risk. Cape Town: Open Society Foundation for South Africa.

UNITED NATIONS OFFICE ON DRUGS AND CRIME (UNODC). 2006. Handbook on restorative justice programs. New York: United Nations.

WOOD, C. 2003. Diversion in South Africa: a review of policy and practice, 1990-2003. Institute for security studies, paper 79. October.

WOODWARD, S.C., SLOTH-NIELSON, J. \& MATHITI, V. 2008. South Africa, the arts and youth in conflict with the law. International Journal of Community Music, 1(1):69-88.

ZEHR, H. 2002. The little book of restorative justice. Good Books: Intercourse, PA.

Dr Roelf Reynecke, Department of Social Work, Adv Mariette Reyneke, Department of Law and Procedure and Law of Evidence, University of the Free State, Bloemfontein, South Africa. 